Article

\title{
Antioxidant and Free Radical Scavenging Capacity of Seed and Shell Essential Oils Extracted from Abrus precatorius (L)
}

\author{
Sunday O. Okoh ${ }^{1,2}$, Olayinka T. Asekun ${ }^{1, *}$, Oluwole B. Familoni ${ }^{1}$ and Anthony J. Afolayan ${ }^{3}$ \\ 1 Department of Chemistry, University of Lagos, Yaba, Lagos 101017, Nigeria; \\ E-Mails: sunnyokoh2003@yahoo.com (S.O.O.); familonio@unilag.edu.ng (O.B.F.) \\ 2 Department of CFET, Federal Institute of Industrial Research, Lagos 100261, Nigeria \\ 3 Department of Botany, University of Fort Hare, Alice 5700, South Africa; \\ E-Mail: aafolayan@ufh.ac.za \\ * Author to whom correspondence should be addressed; E-Mail: oasekun@unilag.edu.ng; \\ Tel.: +234-803-330-2040.
}

Received: 10 January 2014; in revised form: 28 February 2014 / Accepted: 21 March 2014 /

Published: 15 April 2014

\begin{abstract}
Essential oils from plants have been proven safe as natural antioxidants, and few are already marketed as digestive enhancers as well as in prevention of several degenerative diseases. This study evaluated the antioxidant capacity of seed and shell essential oils of Abrus precatorius (L), a herb used for ethno-medicinal practices in Nigeria. The essential oils were obtained by hydro-distillation. The ability of the oils to act as hydrogen/electrons donor or scavenger of radicals were determined by in-vitro antioxidant assays using 2,2-diphenyl-2-picryl-hydrazyl free radical (DPPH') scavenging; 2,2'-azino-bis(3-ethylbenzthiazoline-6-sulfonic acid) (ABTS) radical scavenging; lipid peroxide and nitric oxide radicals scavenging assays. The $\mathrm{IC}_{50}$ of the seed and shell oils $(2.10 \mathrm{mg} / \mathrm{mL}$ and $1.20 \mathrm{mg} / \mathrm{mL}$ respectively) showed that antioxidant activity is higher than that for the standard drugs $(3.20 \mathrm{mg} / \mathrm{mL}$ and $3.40 \mathrm{mg} / \mathrm{mL})$ for the nitric oxide scavenging assay. The lipid peroxidation radical activity of the oils were similar to vitamin $\mathrm{C}$, weak DPPH and ABTS radical scavenging activities were discovered in comparison to vitamin $\mathrm{C}$ and rutin. Generally, in the four antioxidant assays, a significant correlation existed between concentrations of the oils and percentage inhibition of free radicals and lipid peroxidation. The composition of $A$. precatorius essential oils reported earlier may account for their antioxidant capacity.
\end{abstract}


Keywords: Abrus precatorius; essential oils; DPPH; ABTS; lipid peroxidation; nitric oxide

\section{Introduction}

There are increasing evidences that free radicals produced molecular alterations that are associated with various degenerative human diseases such as arteriosclerosis, cancers, Alzheimer's disease, Parkinson's disease, diabetes, asthma, arthritis, immune deficiency diseases and aging [1-4]. Antioxidants are substances that mop up free radicals and prevent them from causing cell damage $[5,6]$. Plants contain antioxidant compounds that function as free radical scavengers, reducing agents and quenchers of singlet oxygen formation [7]. In the last decade, there have been increasing suggestions and demand for use of essential oils as natural antioxidant than any other plant extracts as potential substitute for the synthetic ones [8-10]. Essential oils reduce oxidation within body fluids by inhibiting radicals and increase permeability of microbe's cell membrane leading to perforation and leakage of cell vital intracellular constituent such as potassium ions $\left(\mathrm{K}^{+}\right)$, adenosine triphosphate (ATP), thus preventing growth of pathogens [5,6]. Essential oil has demonstrated superior properties such as ability to penetrate cell membrane and tissues 100 times faster than water; 10,000 times faster than salt and it can penetrate the blood-brain barrier [9]. Studies have shown that these unique properties are due to volatile, lipophilic nature and chemical structure of essential oil compounds as well as their strong potency as free radical quenching agents [11]. The interest in essential oils and their application in food preservation have been amplified in recent years by an increasingly negative consumer perception of synthetic preservatives. Studies have established that the synthetic antioxidants unlike the natural antioxidants cannot be recycled or re-used by the organism once they have donated their electron to quench free radicals, hence they become harmful metabolic byproducts that increase, rather than decreasing the total load of oxidative stress [12,13]. Essential oils contain a variety of volatile compounds called secondary metabolites, important for plant defense and recent biochemical in-vivo studies have characterized some of the compounds as natural antioxidants [14-16]. Studies have also shown that some volatile compounds in essential oils possess strong activity against degenerative diseases including very deadly ones such as breast cancer. Limonene and $\beta$-caryophyllene isolated from essential oils have been documented to exhibit such activities $[15,17,18]$.

Abrus precatorius (L.) belongs to the family Leguiminosae, is commonly called crab eye, and grows in tropical and subtropical climates such as South China, Sri Lanka, Thailand, North America and West Indies [19]. It is prevalent in South West Nigeria. The seeds are considered useful as diuretic, laxative, purgative, emollient, abortifacient and sedative agents. In traditional medicine, it is used to treat itches, sores and wounds. The aqueous and ethanolic extracts of the seed have been reported to contain phenols, tannins, alkaloids, flavonoids and steroids [20]. In our previous reports on the composition of the leaves, seeds and shell of $A$. precatorius plant, monoterpenes, sesquiterpenes, alcohols, phenols and unsaturated fatty acids were documented as the predominant compounds [21]. However, there is dearth of information on the antioxidant capacity, and free radical scavenging activity of the essential oil of the plant. Therefore, this present study was conducted to investigate the antioxidant capacity and free radical scavenging activity of the oils of $A$. precatorius hoping to justify 
its ethno-medicinal uses and expose more avenues of its exploitation. This work is part of an ongoing research aimed at discovering new essential oil plants with bioactive potentials either as flavors or fragrances that are indigenous to Nigeria.

\section{Experimental Section}

\subsection{Chemicals Used}

Potassium persulfate (PPS), 2,2-dipphenyl-1-picrylhydrazyl (DPPH) and 2,2-azinobis-(3ethylbenzothiazolin-6-sulfonic acid) diammonium salt (ABTS) were purchased from Sigma-Aldrich (St Louis, MO, USA). Methanol was purchased from Fluka Chemicals (Buchs, Switzerland). All other chemicals used were analytical grade.

\subsection{Plant Material and Extraction of Essential Oils}

The seeds of $A$. precatorius were collected at the plantation of Forestry Research Institute of Nigeria (FRIN), Ibadan, Nigeria. It was authenticated at the Botany Department, University of Lagos by Mr. T. K. Odewo. A voucher of the plant was deposited in the University of Lagos herbarium. After drying, the shells were separated from the seeds and pulverized. Powdered seeds and shells were separately hydrodistilled using the modified Clevenger apparatus. The oil was captured in steam and extracted into $n$-hexane at $100-110^{\circ} \mathrm{C}$ for $3 \mathrm{~h}$. The oil extracted in $n$-hexane was carefully dispensed, dried with $\mathrm{Na}_{2} \mathrm{SO}_{4}$ and kept in tinted vials at $4{ }^{\circ} \mathrm{C}$ until further analysis. The extraction was carried out several times to get sufficient essential oils for the antioxidant study.

\subsection{DPPH Assay}

The DPPH assay of the essential oil was carried out as previously described [22]. A solution of $0.135 \mathrm{Mm}$ DPPH in methanol was prepared and $1.0 \mathrm{~mL}$ of this solution was mixed with $1.0 \mathrm{~mL}$ of the essential oil prepared in methanol containing $0.025-0.50 \mathrm{mg} / \mathrm{mL}$ of the oil and commercial antioxidants (vitamin $\mathrm{C}$ and rutin). The reaction mixture was vortexed thoroughly, left in the dark at $25{ }^{\circ} \mathrm{C}$ for $30 \mathrm{~min}$ and measured at $517 \mathrm{~nm}$. The ability of the essential oil to scavenge DPPH radical was calculated as $\%$ inhibition by the following equation:

$$
\% \text { inhibition }=\left\{\left(\mathrm{Abs}_{\text {control }}-\mathrm{Abs}_{\text {sample }}\right)\right\} /\left(\mathrm{Abs}_{\text {control }}\right) \times 100
$$

where Abs control is the absorbance of the DPPH radical + methanol; Abs sample is the absorbance of DPPH radical + essential oil or commercial antioxidant. The inhibitory concentration $\left(\mathrm{IC}_{50}\right)$ of the essential oil needed to inhibit $50 \%$ of the DPPH radicals obtained from the standard curve was compared to that of standard/commercial antioxidants (vitamin $\mathrm{C}$ and rutin).

\subsection{ABTS Assay}

In the ABTS free radical assay, the method of Witayapan [23] was adopted with minor changes (ABTS stock solution diluted in methanol). The pre-formed radical mono cation of ABTS was generated by oxidation of ABTS solution $(7 \mathrm{mM})$ with $2.45 \mathrm{mM}$ potassium persulfate solution in equal amount. The mixture was allowed to react for $12 \mathrm{~h}$ in the dark at $25^{\circ} \mathrm{C} .1 \mathrm{~mL}$ of the resulting solution 
was diluted in $60 \mathrm{~mL}$ of methanol to obtain an absorbance of $0.706 \pm 0.001$ at $734 \mathrm{~nm} .1 \mathrm{~mL}$ of the ABTS radical cation solution was added to the $0.025,0.05,0.10,0.2$ and $0.5 \mathrm{mg} / \mathrm{mL}$ of essential oil solutions and commercial antioxidants (vitamin $\mathrm{C}$ and rutin) prepared in methanol and absorbance measured at $734 \mathrm{~nm}$. The percentage inhibition of ABTS radical by the oils was calculated using the equation described in the DPPH assay.

\subsection{Lipid Peroxides Radical Scavenging Capacity}

The Thiobarbituric acid-reactive species (TBARS) assay described by Badmus [24] was used to measure the lipid peroxidation, using egg-yolk homogenates as lipid-rich media with a minor change (methanol used for dilution of oils instead water). Egg homogenate $(0.50 \mathrm{~mL}, 10 \%$ in distilled water, $\mathrm{v} / \mathrm{v}$ ) and the oils $0.025-0.50 \mathrm{mg} / \mathrm{mL}$ in methanol were mixed, the volume was made up to $1 \mathrm{~mL}$, by adding methanol. $0.05 \mathrm{~mL} \mathrm{FeSO}_{4}(0.07 \mathrm{M})$ was added to the mixture and incubated for $30 \mathrm{~min}$, to induce lipid peroxidation. Thereafter, $1.5 \mathrm{~mL}$ of $20 \%$ acetic acid (pH adjusted to 3.5 with $\mathrm{NaOH}$ ) and $1.5 \mathrm{~mL}$ of $0.8 \%$ TBA (w/v) (prepared in $1.1 \%$ sodium dodecyl sulfate) and $0.05 \mathrm{~mL} \mathrm{20 \%} \mathrm{TCA} \mathrm{were}$ added, the test tubes were vortexed and heated in a water bath for $60 \mathrm{~min}$. After cooling, $5.0 \mathrm{~mL}$ of 1-butanol was added and centrifuged at $3000 \mathrm{rpm}$ for $10 \mathrm{~min}$. The absorbance of the organic upper layer was measured at $532 \mathrm{~nm}$. For the blank $0.1 \mathrm{~mL}$ of methanol was used in place of the oil. The percentage of inhibition of lipid peroxide was calculated using the equation described in the DPPH assay.

\subsection{Nitric Oxide Radical Scavenging Capacity}

The method described by Makhija et al. [25] was adopted. Nitric oxides radicals were generated from a sodium nitroprusside solution; Sodium nitroprusside $(1 \mathrm{~mL}$ of $10 \mathrm{mM})$ was mixed with $1 \mathrm{~mL}$ of oils to give concentrations of $0.025-0.50 \mathrm{mg} / \mathrm{mL}$ in phosphate buffer. The mixture was incubated at $25{ }^{\circ} \mathrm{C}$ for $150 \mathrm{~min}$. To $1 \mathrm{~mL}$ of the incubated solution, $1 \mathrm{~mL}$ of Griess' reagent was added. Absorbance was read at $546 \mathrm{~nm}$. The \% inhibition of nitric oxide radical by the oil was calculated using the equation described in the DPPH assay. All measurements were done in triplicates and mean values were calculated.

\subsection{Statistical Analyses}

Data were calculated as means \pm SD. Pearson's correction analysis (SPSS 16.0 for windows, SPSS Inc., Chicago, IL, USA) was used to test for the significance of the relationship between the concentration and percentage inhibition.

\section{Results and Discussion}

The seed and shell essential oils from A. precatorius were examined for radical scavenging and antioxidant activities using four different assay methods. The percentage inhibitions of the oils were concentration dependent.

The percentage inhibitions for DPPH assay are given in Figure 1. At all concentrations $(0.025-0.5 \mathrm{mg} / \mathrm{mL})$ the shell oil showed stronger DPPH radicals scavenging activity than the seed oil. 
However, the oils activity at $0.2 \mathrm{mg} / \mathrm{mL}$ and $0.5 \mathrm{mg} / \mathrm{mL}$ were above average. Overall, rutin demonstrated superior scavenging activity.

The percentage inhibitions pattern of the ABTS radicals was similar to DPPH. However, the seed oil demonstrated stronger inhibitions at concentrations of 0.05 and $0.1 \mathrm{mg} / \mathrm{mL}$ than the shell oil (Figure 2). Vitamin $\mathrm{C}$ had lower activity than the two oils except at concentration of $0.5 \mathrm{mg} / \mathrm{mL}$.

Figure 1. Antioxidant activity of the shell and seed essential oils extracted from A. precatorius on 2,2-diphenyl-2-picryl-hydrazyl free radical (DPPH) radicals.

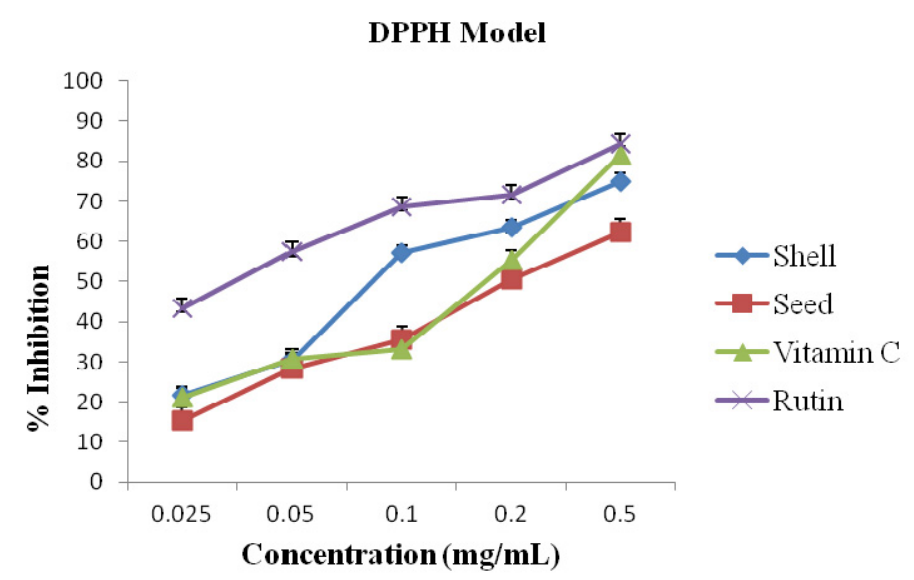

Figure 2. Antioxidant activity of the shell and seed essential oils extracted from A. precatorius on 2, 2'-azino-bis (3-ethylbenzthiazoline-6-sulfonic acid) (ABTS) radicals.

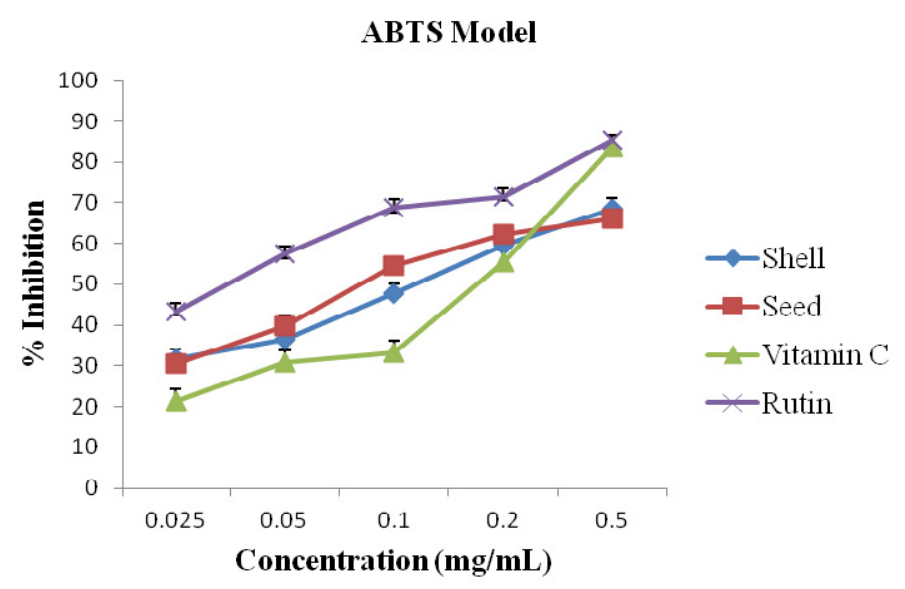

The lipid peroxide radicals scavenging activity of the essential oils results at various concentrations is shown in Figure 3. The shell oil displayed a stronger lipid peroxide radicals scavenging activity than the seed oil and the two standard antioxidants at $0.025-0.10 \mathrm{mg} / \mathrm{mL}$. At all concentrations, the shell oil demonstrated superior lipid peroxide radicals scavenging activity than the seed oil. Notable is the significant difference in lipid peroxide radicals scavenging activity between the shell oil and vitamin $\mathrm{C}$.

The radicals scavenging activity of the seed and shell essential oils from $A$. precatorius in nitric oxides rich (NO) medium at various concentrations are presented in Figure 4. The percentages of inhibition of the shell oil were higher than that of the seed oil, this is comparable to the lipid assay result. The activity of the oils was higher than that of vitamin $\mathrm{C}$ and comparable to rutin. 
It has been established that DPPH test does not discriminate between radical species, but generally ideal for radicals quenching ability [2]. Hence, for quantitative and qualitative antioxidant capacity of the oils, we examined suspected antioxidant activity using four radical quenching assays. In the series of the in vitro tests the seed and shell essential oils of $A$. precatorius exhibited significant antioxidant activity by acting as donators of proton or electron in the DPPH, ABTS assays and possessed hydroxyl, lipid peroxide and nitric oxide radical scavenging properties. In all four assays, the shell and seed oils possessed greater activity than vitamin $\mathrm{C}$. These results are presented in Figures $1-4$, the $\mathrm{IC}_{50}$ values for the oils are presented in Table 1.

Figure 3. Antioxidant activity of the shell and seed essential oils extracted from A. precatorius on lipid peroxide radicals.

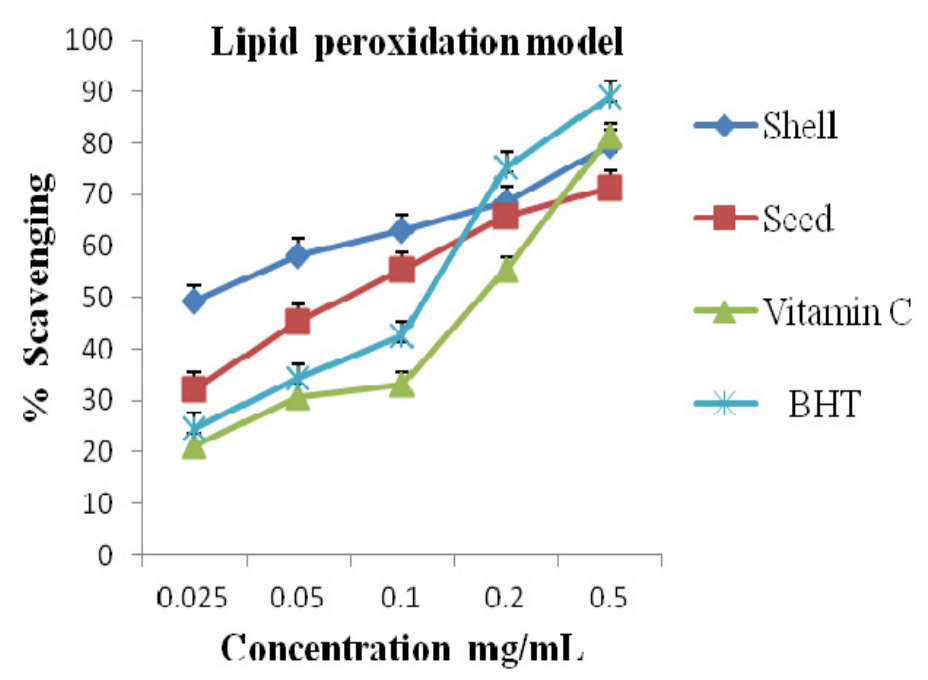

Figure 4. Antioxidant activity of the shell and seed essential oils extracted from A. precatorius on nitric oxide radicals.

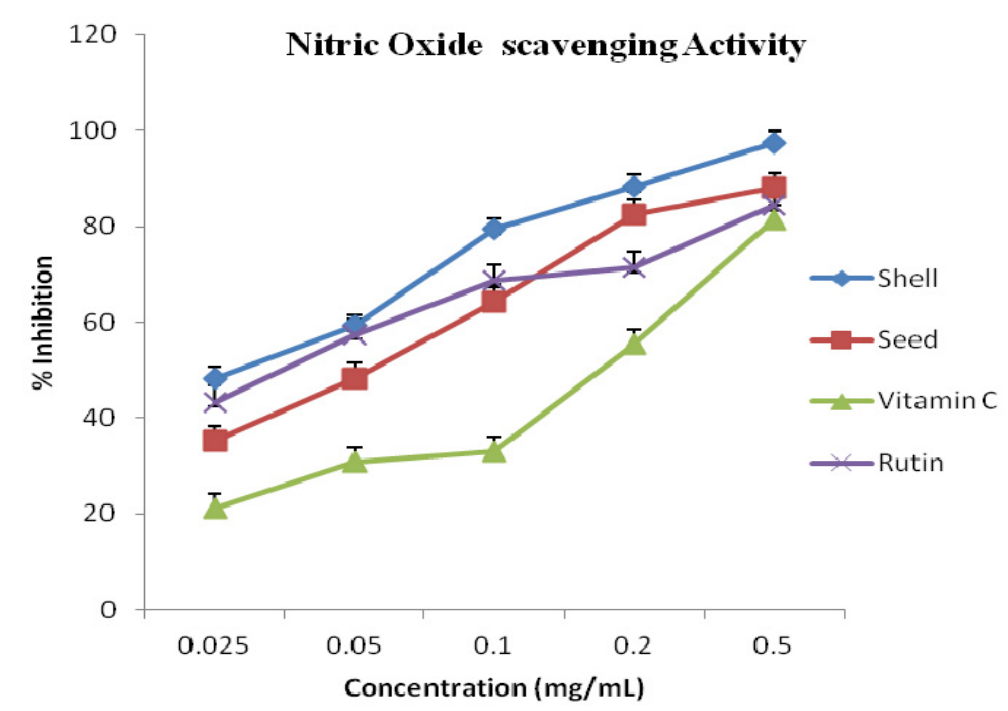


Table 1. Antioxidant capacity of essential oils of A.precatorius $(\mathrm{mg} / \mathrm{mL})$.

\begin{tabular}{|c|c|c|c|c|c|c|}
\hline \multirow{2}{*}{$\mathbf{S} / \mathbf{N}$} & \multirow{2}{*}{ Activity } & \multicolumn{2}{|c|}{ A. precatorius } & \multicolumn{3}{|c|}{$\begin{array}{c}\text { Standard/Commercial Antioxidants } \\
\text { (Positive Controls) }\end{array}$} \\
\hline & & $\begin{array}{c}\text { Seed Oil } \\
\left(\mathrm{IC}_{50}\right)\end{array}$ & $\begin{array}{c}\text { Shell Oil } \\
\left(\mathrm{IC}_{50}\right)\end{array}$ & Vitamin $\mathrm{C}\left(\mathrm{IC}_{50}\right)$ & Rutin $\left(\mathrm{IC}_{50}\right)$ & $\mathrm{BHT}^{\mathrm{b}}\left(\mathrm{IC}_{50}\right)$ \\
\hline 1 & $\mathrm{DPPH}^{\circ}$ & $5.03 \pm 0.24$ & $3.03 \pm 0.11$ & $1.50 \pm 0.01$ & $0.50 \pm 0.04$ & ND \\
\hline 2 & $\operatorname{ABTS}^{+}$ & $2.95 \pm 0.31$ & $3.07 \pm 0.22$ & $0.10 \pm 0.04$ & $0.10 \pm 0.01$ & ND \\
\hline 3 & $\mathrm{LP}^{\bullet}$ & $1.92 \pm 2.10$ & $1.42 \pm 0.40$ & $1.83 \pm 0.33$ & ND & $0.83 \pm 0.40$ \\
\hline 4 & $\mathrm{NO}^{\circ}$ & $2.10 \pm 0.40$ & $1.20 \pm 0.20$ & $1.20 \pm 0.20$ & $3.40 \pm 0.01$ & ND \\
\hline
\end{tabular}

$\mathrm{DPPH}^{\bullet}=$ 2,2-diphenylpicrylhydrazyl radicals, $\mathrm{ABTS}^{\bullet}=2,2^{\prime}$-azino-bis diammonium salt radicals, $\mathrm{LP}^{\bullet}=$ lipid peroxide radical, $\mathrm{NO}^{\bullet}=$ Nitric oxide radical, ${ }^{\mathrm{b}}$ BHT $=$ Butylated hydroxyl toluene, ND $=$ Not determined, the lower $\mathrm{IC}_{50}(\mathrm{mg} / \mathrm{mL})$ the higher the antioxidant capacity. Values are mean $\pm \mathrm{SD}, n=3$.

The seed and shell oils were able to reduce the stable DPPH radical to $50 \%$ reduction with $\mathrm{IC}_{50}$ of $5.03 \pm 0.24$ and $3.03 \pm 0.11 \mathrm{mg} / \mathrm{mL}$ respectively. The antioxidant capacity of the two oils in the DPPH radicals assay were lower than those of the standard antioxidants (vitamin $\mathrm{C}$ and rutin). The seed oil was more effective in scavenging ABTS radicals than the DPPH radicals with $\mathrm{IC}_{50}$ values $2.95 \pm 0.31$ and $5.03 \pm 0.24 \mathrm{mg} / \mathrm{mL}$ respectively, this might be due to the fact that the complexity of essential oils, polarity and chemical properties, could lead to varying bioactivity results depending on the method adopted [26]. The shell oil activity in both assays was similar $(3.03 \pm 0.11$ and $3.07 \pm 0.22 \mathrm{mg} / \mathrm{mL})$. The shell oil was able to inhibits the lipid peroxides radicals more than the seed oil and vitamin $\mathrm{C}$ with $\mathrm{IC}_{50}$ value of $1.42 \pm 0.40 \mathrm{mg} / \mathrm{mL}$. However, BHT demonstrated significantly higher antioxidant capacity $(0.83 \pm 0.4 \mathrm{mg} / \mathrm{mL})$. In the nitric oxide radical test, the oils and standards effectively reduced the generated NO radicals. They exhibited strong $\mathrm{NO}$ radical scavenging capacity with valuable $\mathrm{IC}_{50}$ of $2.10 \pm 0.40,1.20 \pm 0.20$ and $3.4 \pm 0.01,3.2 \pm 0.02 \mathrm{mg} / \mathrm{mL}$ respectively. Interestingly, the shell and seed oils displayed superior capacity than vitamin $C$ and rutin. Factors like stereo-selectivity of the radicals or the solubility of the oil in the different testing systems have also been reported to affect the capacity of essential oils in quenching different radicals [26]. Wang et al. [12] reported that some compounds, which have ABTS radicals scavenging activity, do not show DPPH activity. Hence, the ability of the seed and shell essential oils of $A$. precatorius to scavenge different free radicals in different systems is noteworthy. This indicates that the oils may be useful for preventing radical related pathological damage, especially breakdown of biomolecules and DNA by LP and NO radicals that may lead to arteriosclerosis, carcinogenesis and inflammation [27]. Several studies have shown that chronic expression of NO radicals is associated with inflammation conditions including juvenile diabetes, multiple sclerosis, arthritis, ulcerative colitis [28,29]. The GC/MS quantitative and qualitative investigation of the leaf, seed and shell essential oils of A. precatorius in our previous report [21], revealed the presence of terpenes, phenol, alcohols, terpenoids and unsaturated fatty acids as prominent compounds. The major monoterpenes compounds in shell oil were limonene (19.08\%), ocimene (8.94\%) and myrcene (8.60\%), while zingiberene $(6.02 \%)$ and $\beta$-bisabolene $(3.92 \%)$ were the prominent sesquiterpenes. Other important compounds identified in the shell oil are, camphene (6.75\%), $\alpha$-pinene (4.18\%), curcumene (3.10\%), $\alpha$-terpineol $(2.34 \%)$ and methyl eugenol $(0.26 \%)$. In seed oil the dominant monoterpenes are sabinene $(10.93 \%)$ and camphene $(6.45 \%)$, while were zingiberene (10.75\%), farnesene (5.30\%), sesquiphelladrene $(4.47 \%)$ and curcumene $(4.41 \%)$ were the 
prominent sesquiterpenes. Two unsaturated fatty (9,12-octadecedienoic $10.92 \%$ and 10 -octadecenoic $3.16 \%$ ) acids were also compounds identified in the seed oil. These compounds could be responsible for the substantial antioxidant capacity demonstrated by the essential oils, suggesting possible additive or synergist effects of the constituents [30]. The findings in this study are in agreement with previous essential oil researchers, that some essential oils are strong natural antioxidants [31,32].

\section{Conclusions}

This study shows that besides the traditional uses of the plant extract, the essential oils extracted from $A$. precatorius seeds and shells have good antioxidant potential, and could probably replace synthetic antioxidants in further studies.

\section{Acknowledgments}

This research was supported by University of Lagos STEP B World Bank Project in Nigeria and Govan Mbeki Research and Development Centre, University of Fort Hare, South Africa.

\section{Author Contributions}

O.T.A and O.B.F designed the experiments. S.O.O. performed the essential oil isolation and antioxidant experiments. A.J.A and O.T.A supervised the isolation and antioxidant experiments. S.O.O. and O.T.A both prepared the manuscript.

\section{Conflicts of Interest}

The authors declare no conflict of interest.

\section{References}

1. Saikat, S.; Chakraborty, R.; Sridhar, C.Y.; Reddy, S.R.; Biplab, D. Free radicals, antioxidants, diseases and phytomedicine: Current status and future prospect. Int. J. Pharm. Sci. Rev. Res. 2010, 3, 91-100.

2. Sachdev, S.; Davies, K. Production, detection, and adaptive responses to free radicals in exercise. Free Radic. Biol. Med. 2008, 44, 215-223.

3. Mahmood, R.M.; Soheila, M.; Saeid, A. Radical scavenging and reducing power of Salvia mirzayanii subfractions. Molecules 2008, 13, 2804-2813.

4. Mimica-Dukic, N.; Dušan, B.; Slavenko, M.; Dragana, V.G.; Branka, O.D. Essential oil of Myrtus communis L. as a potential antioxidant and antimutagenic agents. Molecules 2010, 15, 2759-2770.

5. Paul, S. Trachyspermum ammi (L.). Fruit essential oil influencing on membrane permeability and surface characteristics in inhibiting food-borne pathogens. Food Control 2011, 22, 725-731.

6. Morten, H.; Mygind, T.; Rikke, L. Essential oils in food preservation: Mode of action, synergies, and interactions with food matrix components. Front. Microbiol. 2012, 3, 12. 
7. Millogo-Kone, M.; Lompo, F.; Nacoulma, O. Evaluation of flavonoids, total phenolic contents of P. biglobosa and free radical scavenging and antimicrobial activities. Res. J. Med. Sci. 2009, 3, 70-74.

8. Brenes, A.; Roura, E. Essential oils in poultry nutrition: Main effects and modes of action. Anim. Feed Sci. Technol. 2010, 158, 1-14.

9. Nweze, E.I.; Okafor, J.I. Activities of a wide range of medicinal plants and essential oil against Scedospaorium isolates. Am. Eurasian J. Sci. Res. 2010, 5, 161-169.

10. Tuttolomondo, T.; Virga, G.; Curcuruto, G.; la Bella, S.; Leto, C.; Licata, M.; Napoli, E.; Pasquale, A.; Saija, A.; Siracusa, L.; et al. Biomolecular characterization of wild sicilian oregano: Phytochemical screening of essential oils and extracts, and evaluation of their antioxidant activities. Chem. Biodivers. 2013, 10, 411-433.

11. Mansoub, N.; Myandoab, P. Research opinion in animal. Vet. Sci. 2012, 2, 7-9.

12. Wang, W.; Wu, N.; Zu, G.; Fu, Y. Antioxidant activity of Rosmarinus officinalis (L), essential oil compared to its main components. Food Chem. 2008, 108, 1019-1022.

13. Miller, E.R.; Pastor-Barriuso, R.; Dalal, D.; Riemersma, R.A.; Appel, L.J.; Guallar, E. Vitamin E supplementation may increase all-cause mortality. Ann. Intern. Med. 2005, 1, 37-46.

14. Jesudoss, V.A.; Jayaraman, J.; Madhavan, S. D-limonene alleviates insulin resistance and oxidative stress in rat. Eur. J. Nutr. 2012, 51, 57-68.

15. Horvathova, E.; Katarina, K.; Srancikova, A.; Hunakova, L.; Galova, E.; Sevcovicova, A.; Slamenova, D. Borneol administration protects primary rat hepatocytes against exogenous oxidative DNA damage. Mutagenesis 2012, 27, 581-588.

16. Bidinotto, L.T.; Costa, C.A.; Salvadori, D.M.; Costa, M.; Rodrigues, M.A.; Barbisan, L.F. Effects lemongrass oil on DNA damage and carcinogenesis in female mice. J. Appl. Toxicol. 2011, 31, 536-544.

17. Kaurinovic, B.; Vlaisavljevic, S.; Popovic, M.; Vastag, D.; Djurendic-Brenesel, M. Antioxidant properties of Marrubium peregrinum essential oil. Molecules 2010, 15, 5943-5955.

18. Avlessi, F.; Alitonou, G.A.; Sohounhloue, D.K.; Bessiere, J.M.; Menut, C. Chemical and Biological evaluation of leaf essential oil of Commiphora africana from Benin. J. Essent. Oil Res. 2005, 17, 569.

19. John, D.B.; Benjamin, P.J.; Rathna, K.; Herin, D.S. Abrus precatorius L.: A medicinal plant with potential as antibacterial agent. J. Pharm. Res. 2012, 5, 1207-1209.

20. Pal, R.S.; Ariharasivakumar, G.; Girhepunje, K.; Upadhyay, A. In vitro antioxidant activity of phenolic and flavonoids compounds extracted from seeds of Abrus precatorius. Int. J. Pharm. Pharm. Sci. 2009, 1, 136-140.

21. Okoh, S.O.; Asekun, O.T.; Familoni, O.B. The essential oils and chemical composition of leaf, seed and shell of Abrus precatorius from Nigeria. In Proceedings of the 4th Annual Research Conference and Fair, 2008, University of Lagos, Lagos, Nigeria, 8 January 2009; University of Lagos Press: Lagos, Nigeria, 2009.

22. Okoh, S.O.; Asekun, O.T.; Familoni, O.B.; Afolayan, A.J. Composition and antioxidant activities of leaf and root volatile oils of Morida lucida. J. Nat. Prod. Commun. 2011, 6, 1537-1541.

23. Witayapan, N.; Sombat, C.; Siriporn, O. Antioxidant and antimicrobial activities of Hyptis suaveolens essential oil. Sci. Pharm. 2007, 75, 35-46. 
24. Badmus, J.A.; Odunola, O.A.; Obuotor, E. Phytochemical and in vitro antioxidant potentials of Holarrhena floribunda leaf. Afr. J. Biotechnol. 2010, 9, 340-346.

25. Makhija, I.K.; Aswatha Ram, H.N.; Shreedhara, C.S.; Vijay Kumar, S.; Devkar, R. In vitro antioxidant studies of Sitopaladi Churna, a polyherbal Ayurvedic formulation. Free Radic. Antioxid. 2011, $1,37-41$.

26. Guerrini, A.; Sacchetti, G.; Rossi, D.; Paganetto, G.; Muzzoli, M.; Andreotti, E. Bioactivities of Piper aduncum L. and Piper obliquum Ruiz \& Pavon (Piperaceae) essential oils from Eastern Ecuador. Environ. Toxicol. Pharmacol. 2009, 27, 39-48.

27. Valko, M.; Leibfritz, D.; Moncol, J.; Mazur, M.; Telser, J. Free radicals and antioxidants in normal physiological functions and human disease. Int. J. Biochem. Cell Biol. 2007, 39, 44-84.

28. Sathyavathi, A.; Suchetha, N.; Vijay, R.; Ullal, D.; Praveen, A. Status of Phosphodiesterase, Nirtic oxide and Arginase levels in hypo and hyperthyroidism. Int. J. Res. Pharm. Biomed. Sci. 2012, 3, 541-544.

29. Fini, M.A.; Johnson, R.J.; Stenmark, K.R.; Wright, R.M. Hypertension, nitrate-nitrite, and xanthine oxidoreductase catalyzed nitric oxide generation: Pros and Cons. Hypertension 2013, 62, e9.

30. Luh, S.; Wong, S.; El-shimi, E. Effect of processing on some chemical constituents of Pistachio nuts. J. Food Qual. 2007, 5, 33-41.

31. Foti, M.C.; Ingold, K.U. Unexpected superoxide dismutase antioxidant activity of Ferric chloride in acetonitrile. J. Org. Chem. 2009, 68, 9162-9125.

32. Peana, A.; Marzocco, S.; Popolo, A. Linalool inhibits in vitro NO formation: Probable involvement in the antinociceptive activity of this monoterpene compound. Life Sci. 2006, 78, 719-723.

(C) 2014 by the authors; licensee MDPI, Basel, Switzerland. This article is an open access article distributed under the terms and conditions of the Creative Commons Attribution license (http://creativecommons.org/licenses/by/3.0/). 